\title{
Climate Policy
}

\section{polsc}

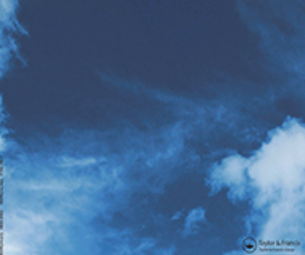

ISSN: 1469-3062 (Print) 1752-7457 (Online) Journal homepage: https://www.tandfonline.com/loi/tcpo20

\section{Assessing the ambition of post-2020 climate targets: a comprehensive framework}

\author{
Niklas Höhne, Hanna Fekete, Michel G.J. den Elzen, Andries F. Hof \& Takeshi \\ Kuramochi
}

To cite this article: Niklas Höhne, Hanna Fekete, Michel G.J. den Elzen, Andries F. Hof \& Takeshi Kuramochi (2018) Assessing the ambition of post-2020 climate targets: a comprehensive framework, Climate Policy, 18:4, 425-441, DOI: 10.1080/14693062.2017.1294046

To link to this article: https://doi.org/10.1080/14693062.2017.1294046

\section{+ View supplementary material $\widetilde{ }$}

曲 Published online: 29 Mar 2017.

Submit your article to this journal

Џlll Article views: 802

View Crossmark data

Citing articles: 9 View citing articles 


\title{
Assessing the ambition of post-2020 climate targets: a comprehensive framework
}

\author{
Niklas Höhne (iD) ${ }^{a, b}$, Hanna Fekete ${ }^{a}$, Michel G.J. den Elzen (1D), Andries F. Hof $\mathbb{D}^{c, d}$ and \\ Takeshi Kuramochi (iD ${ }^{\text {a }}$
}

${ }^{a}$ NewClimate Institute, Cologne, Germany; ${ }^{b}$ Environmental Systems Analysis Group, Wageningen University, Wageningen, Netherlands; ${ }^{C}$ PBL Netherlands Environmental Assessment Agency, The Hague, Netherlands; ${ }^{\mathrm{d} C o p e r n i c u s ~ I n s t i t u t e ~ o f ~ S u s t a i n a b l e ~}$ Development, Utrecht University, Utrecht, Netherlands

\begin{abstract}
One of the most fundamental questions surrounding the new Paris Agreement is whether countries' proposals to reduce GHG emissions after 2020 are equally ambitious, considering differences in circumstances between countries. We review a variety of approaches to assess the ambition of the GHG emission reduction proposals by countries. The approaches are applied illustratively to the mitigation part of the post-2020 climate proposals (nationally determined contributions, or NDCs) by China, the EU, and the US. The analysis reveals several clear trends, even though the results differ per individual assessment approach. We recommend that such a comprehensive ambition assessment framework, employing a large variety of approaches, is used in the future to capture a wide spectrum of perspectives on ambition.

\section{POLICY RELEVANCE}

Assessing the ambition of the national climate proposals is particularly important as the Paris Agreement asks for regular reviews of national contributions, keeping in mind that countries raise their ambition over time. Such an assessment will be an important part of the regular global stocktake that will take place every five years, starting with a 'light' version in 2018. However, comprehensive methods to assess the proposals are lacking. This article provides such a comprehensive assessment framework.
\end{abstract}

\section{ARTICLE HISTORY}

Received 30 June 2016

Accepted 7 February 2017

\section{KEYWORDS}

ambition; global stocktake; INDCs; NDCs; Paris agreement; UNFCCC

\section{Introduction}

At the 21st session of the Conference of the Parties (COP21) to the United Nations Framework Convention on Climate Change (UNFCCC) held in 2015, the Paris Agreement was adopted as the new international climate policy agreement for the post-2020 period (UNFCCC, 2015a). The Agreement subsequently entered into force on 4 November 2016 after it had been ratified by the required number of countries.

In the lead-up to COP21, countries were asked to put forward proposals on how, and by how much, they are willing to reduce their GHG emissions after 2020; these are the so-called 'intended nationally determined contributions' (INDCs). ${ }^{1}$ Nearly 190 countries submitted their INDCs before the COP21 (Höhne et al., 2016; UNFCCC, $2015 \mathrm{~b}$ ). With each country's ratification of the Paris Agreement, its 'intended nationally determined contribution, INDC' turns into a 'nationally determined contribution, NDC'.

In order to effectively implement and achieve the goals of the Paris Agreement, i.e. to hold the increase in the global average temperature to well below $2^{\circ} \mathrm{C}$ above pre-industrial levels and pursue efforts to limit it to $1.5^{\circ} \mathrm{C}$ (UNFCCC, 2015a), the total ambition level of the NDCs needs to be increased (Rogelj et al., 2016). To guide this process, the NDCs of countries will have to be assessed on their relative ambition level. Indeed, the Paris 
Agreement (Article 4) specifically mentions that 'each Party's successive nationally determined contribution will (...) reflect its highest possible ambition, reflecting its common but differentiated responsibilities and respective capabilities, in the light of different national circumstances'. Countries have thus confirmed their intention to share reductions according to 'common but differentiated responsibilities and respective capabilities' (CBDRRC). Interpretations of this principle, however, still diverge (Meinshausen et al., 2015; Winkler \& Rajamani, 2014). Assessments of ambition will continuously take place, in particular at the 'facilitative dialogue' that is planned for 2018 and at the global 'stocktake' to be held every five years starting 2023. Assessment methodologies for these events are urgently needed.

The EU, China, and the US were among the first to announce a proposal for their efforts in the 2015 climate agreement. The EU proposed to reduce its domestic GHG emissions by at least $40 \%$ by 2030 (European Council, 2014). This was followed by joint announcements by China and the US (White House, 2014), according to which China aimed to peak $\mathrm{CO}_{2}$ emissions by around 2030, make best efforts to peak earlier than this date, and to reach around $20 \%$ of non-fossil fuels in their primary energy consumption by 2030 . The INDC from the US registered an aim to reach 26-28\% reductions in GHG emissions below the 2005 level by 2025 . All three officially submitted their INDCs ahead of the Paris conference. From the announcement to the submission of its INDC, China added an additional element, of a reduction in $\mathrm{CO}_{2}$ emissions by unit of gross domestic product (GDP) by $60-65 \%$ from 2005 to 2030 .

Judging the fairness and relative ambition of countries' contributions to reduce GHG emissions is not easy, as countries have different types of targets and differ in terms of development, industrial structure, capabilities and responsibilities - aspects which also change over time. Many approaches to judge contributions have been introduced and no single approach is 'better' than the other; they all have their pros and cons (den Elzen, Höhne, \& van Vliet, 2009; Stavins et al., 2014). The approaches may come to different results on the relative ambition level of countries. Current literature assessments focus on (1) where countries need to be in 2030 to be compatible with the $2^{\circ} \mathrm{C}$ objective based on effort-sharing approaches (Hof, den Elzen, \& Mendoza Beltran, 2016; Höhne, den Elzen, \& Escalante, 2014a; Kuramochi, Asuka, Fekete, Tamura, \& Höhne, 2015; Meinshausen et al., 2015), (2) global cost-effective distributions (Clarke et al., 2014; Tavoni et al., 2015), or (3) a set of different metrics related to emissions, energy and carbon prices, as well as GHG abatement costs (Aldy, Pizer, \& Akimoto, 2016). However, assessments of national emission reduction proposals based on a comprehensive set of comparability metrics (Aldy et al., 2016) or approaches to evaluate the ambition level of reduction proposals, are limited (Kuramochi, 2015). This is especially the case for peer-reviewed literature on comparisons of post-2020 emission reduction proposals of the three highest-emitting economies - China, the EU, and the US (Aldy et al., 2016).

We argue that to evaluate the ambition level of NDCs, a comprehensive assessment of several approaches should be used that reflect the different viewpoints of the Parties under the UNFCCC. In this context, the main objective of this article is to provide an overview of assessment approaches, and to assess their pros, cons, and results, so that a comprehensive framework of approaches to evaluate the ambition level of NDCs can be designed.

We focus on mitigation only, acknowledging that other elements, such as adaptation and financial support, are also very important. Our framework is based on a review of existing evaluation approaches, in which the approaches are described and evaluated using relevant characteristics, and in which their main challenges are assessed (Section 2). In Section 3, we apply these approaches illustratively for the NDCs by China, the EU, and the US, ranking for each approach the respective ambition. Finally, we draw conclusions from the analysis and identify further research needs (Section 4).

\section{Review of approaches to assess the ambition of NDCs}

A large number of studies have assessed countries' mitigation efforts since COP3 held in Kyoto in 1997 (Aldy et al., 2016). In addition, in recent years, several approaches and associated comparability metrics or indicators have been proposed to evaluate the ambition level of NDCs (Aldy et al., 2016; Höhne, Ellerman, \& Fekete, 2014b; Kuramochi, 2015; NIES, 2015). From this literature, we have identified eight distinct approaches (Table 1). 


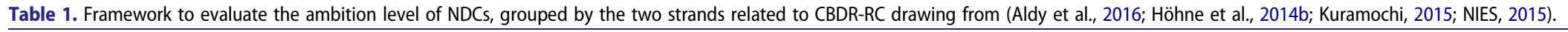

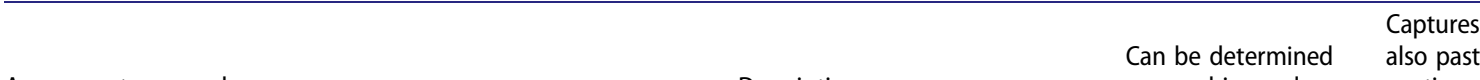

Assessment approach

Description

Approaches related mainly to moral obligation:

1. Reduction from 1990 levels

2. Change in recent trends (Höhne et al, 2014b)

3. Time and level of peaking per capita emissions

4. Effort-sharing (Höhne et al., 2014a)

Approaches related mainly to technical

5. Decarbonization indicators (Aldy et al.

2016; Höhne et al., 2011; Höhne et al.,

2014b; Linthorst, de Beer, Blok, \&

Meindertsma, 2014; NIES, 2015)
In the framework convention adopted in 1992, the base year of 1990 was introduced, as it states the general goal of returning emissions of developed countries by the end of the century to the level of 1990. Since then the base year for 1990 is a common comparison for developed countries.

One can assess whether the new offer constitutes a change in recent trends, indicating that additional action is required to meet the NDC. This acknowledges that all countries need to change their trend; they need to do something new or additional compared to the past (unless they are on a trajectory to zero or negative emissions).

All countries have to undergo a transition where at some point GHG emissions per capita or per GDP peak and then decline. The UNFCCC Copenhagen Accord and the Cancun Agreements (UNFCCC, 2010a, 2010b) called for the peaking of national emissions as soon as possible.

A wide range of literature allocates global emissions and emission reduction targets to individual countries based on 'effort-sharing' principles to determine 'fair' ambition levels. The principles include responsibility (e.g. those who emitted more in the past now have to reduce more) or capability (e.g. those with higher per capita income levels should do more), equality (i.e. equal emission rights per capita), cost-effectiveness (total abatement cost per GDP), as well as combinations.

\section{cessity:}

A number of disaggregated indicators can be used to compare countries' circumstances and developments. On the national level: status of emissions per capita, energy use per capita, or emission intensity of the energy mix. On the sectoral level: emissions per kilometre travelled or per ton of cement or steel produced. Indicators can measure activity (e.g. vehicle kilometres travelled) or intensity (emissions per vehicle kilometre)

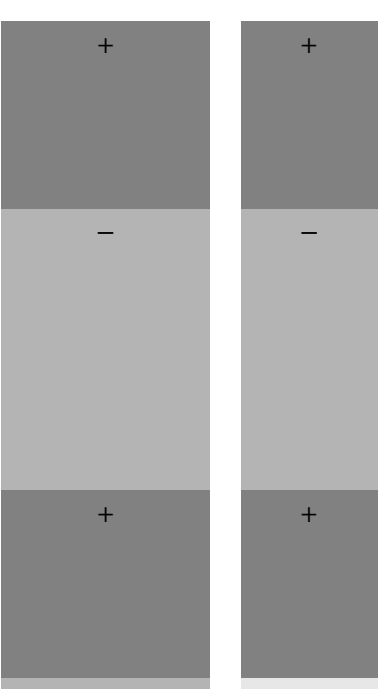

$+1-$

Can only be applied to developed countries.

If evaluated on per capita emissions (not absolute emissions), it can also take into account changes in population since 1990 .

'Recent trends' can have very different definitions; it may exclude existing policies ('no policies' baseline) or assume that all currently existing policies continue ('current policies' scenario). In fact, for countries that made significant efforts in the past, a deviation from recent trends may be more difficult.

Recent trends always remain counterfactual, as they always depend on a (hypothetical) emission projection and cannot be verified.

A 'fair' level of peaking is not equal for all countries as it depends on the time when it occurs. Owing to technological progress, a country that peaks later can reach the same development status with less emissions. It is difficult to determine to which exact amount.

The range of possible emissions allowances is wide owing to the different focus of the effort-sharing approaches. There is also large uncertainty and debate as to the level of global carbon budget to achieve the $2{ }^{\circ} \mathrm{C}$ target with a relatively high probability, an assumption that significantly drives the results.

Some assumptions about the future may be required for some indicators. Emissions per GDP need GDP forecasts, emissions per vehicle kilometre may need modelling.

Many factors that are unrelated to mitigation policies can affect these indicators. 
Table 1. Continued.

\begin{tabular}{|c|c|c|c|}
\hline Assessment approach & Description & $\begin{array}{l}\text { Can be determined } \\
\text { unambiguously }\end{array}$ & $\begin{array}{c}\text { Captures } \\
\text { also past } \\
\text { action }\end{array}$ \\
\hline $\begin{array}{l}\text { 6. Globally cost-effective scenarios (Aldy } \\
\text { et al., 2016; Höhne et al., 2014b) }\end{array}$ & $\begin{array}{l}\text { Modelling exercises can identify necessary reductions } \\
\text { by countries if the aggregated global costs of } \\
\text { emission reductions are minimized. As a result, } \\
\text { reductions are achieved in the sectors and countries } \\
\text { where they are the cheapest from a global } \\
\text { perspective. }\end{array}$ & - & + \\
\hline $\begin{array}{l}\text { 7. Policy package or a policy menu (Höhne } \\
\text { et al., 2014b) }\end{array}$ & $\begin{array}{l}\text { One can compare the extent to which a country } \\
\text { implemented supporting policies, addresses barriers, } \\
\text { or has counterproductive policies in place. A } \\
\text { contribution can be regarded as ambitious if it } \\
\text { includes many policies that are considered good } \\
\text { practice, while it would be less ambitious if the } \\
\text { country would not implement the policies that most } \\
\text { of its peers have already successfully implemented. }\end{array}$ & - & + \\
\hline $\begin{array}{l}\text { 8. Energy price indicators (including carbon } \\
\text { price) (Aldy et al., 2016) }\end{array}$ & $\begin{array}{l}\text { Fossil energy prices (including all taxes and exceptions } \\
\text { and implicit and explicit carbon prices) allow for a } \\
\text { comprehensive assessment of all price-based policies } \\
\text { implemented in the country. The energy prices are a } \\
\text { key driver for energy demand and supply as well as } \\
\text { investment in energy efficient technologies in the } \\
\text { end-use sectors. }\end{array}$ & - & + \\
\hline
\end{tabular}

Challenges

The calculation of mitigation potentials depends on many assumptions, including a no-policy businessas-usual or recent trend plus assumptions of e.g.

future energy prices. This results in limited transparency of the calculations and large differences of the results across models or studies. The critical element of this approach is the definition of the list of good practice policies that are used as the benchmark. There may be a debate over a list of policies to be evaluated because suitable policies may depend largely on national circumstances.

Energy prices fail to capture most effects of non-price based policies that reduce emissions without influencing energy prices.

A low energy prices does not necessarily have to be an indication of low ambition. For example, high shares of renewables in the electricity market may significantly decrease the electricity prices.

Moreover, there are large regional disparities in

natural gas and coal prices owing to the differences in fossil energy resource availability and transportation constraints.

There is also question of whether to look into prices of individual energy sources in different sectors or take the average energy prices of the entire economy. 
For each evaluation approach, Table 1 provides a description, an assessment of its different characteristics and challenges, as well as an indication on whether it focusses on one of two main strands that relate to the principle of $\mathrm{CBDR}-\mathrm{RC}^{2}$ :

- Moral obligation/equity: From this viewpoint, emission commitments should be based on countries' moral obligations to reduce their emissions, so that the resulting regime is equitable and fair. This strand relates to the 'differentiated' element of the agreed principle of CBDR-RC. Differentiation is often based on indicators such as historical responsibility and capability.

- Technical necessity/efficiency: The starting point of this viewpoint is whether a country's proposal is in line with what is technically necessary from now on for a given global goal, irrespective of moral obligation, equity or past action. This could be judged by whether the country's proposal (1) is in line with its contribution in globally cost-effective mitigation scenarios, (2) leverages all mitigation potential, or (3) covers all policies that the country's peers undertake. This strand relates more to the 'common' element of the agreed principle of CBDR$\mathrm{RC}$ and can also be referred to as 'required by science'.

For this article we consider 'ambition' to include both moral obligation and technical necessity. Although some would consider only moral obligation, fairness, or equity as ambition, here we take a wider approach in order to cover as many viewpoints as possible.

The two strands may lead to fundamentally different outcomes. A developing country, for example, may have limited moral obligation because of its low historical emissions, but at the same time, high mitigation potential, as in general developing countries tend to be characterized by higher energy and carbon intensities, rapidly rising baseline emissions, and by a high share of new infrastructure (Clarke et al., 2014). Many developed countries, in contrast, have a high moral obligation, but may also face higher technical difficulties to reduce domestic emissions by the same order of magnitude without retiring old infrastructure before the end of its life ('carbon lock-in' or 'stranded assets') leading to relatively high costs. Countries with high moral obligation but low domestic technical potential could provide technical and financial support to other countries to implement what is technically necessary. We grouped the approaches according to whether they relate more to moral obligation or technical necessity, although some approaches may relate to both elements in different degrees.

We also assessed the different methods against two further important characteristics, and discuss their main challenges in this regard (Table 1):

- Can be determined unambiguously: Some of the approaches are straightforward to calculate and the results will not depend on the entity that is applying the approach, and its parameterization. Other approaches allow for different interpretation and parameter settings and therefore different users will yield different results.

- Captures also past action of countries: The NDCs are primarily intentions for the future. But future mitigation action may depend on (the lack of) past actions. An approach for rating future action could therefore also take into account past actions of a country, to put the future actions in better perspective.

The overview presented in Table 1 shows that each approach has strengths but also weaknesses, and no single approach stands out. Although the simplest approach of 'reduction of GHG emissions from 1990 levels' can be determined unambiguously and takes into account past action, it is not a good indicator to compare the relative ambition levels of countries which differ in their stages of development, as these usually show very different emission trends. Time and level of peaking is easy to calculate, but difficult to interpret, as it is difficult to determine how much lower a peak should be attributable to technological progress if it occurs later. Change in recent trends is difficult to calculate as 'recent trends' can be defined in different ways. Decarbonization indicators are close to actual action in the sectors, but can only capture the difference in national circumstances between countries to a limited extent. The same holds for comparison to best practice policies, which is difficult to obtain and very difficult to differentiate among countries according to equity principles. 


\section{Illustrative assessment}

In this section, we assess the NDCs of China, the EU, and the US by applying seven of the assessment approaches $^{3}$ presented in Table 1, and then compare them qualitatively. Data sources used across the approaches are described in the appendix (Supplementary Information). The results of the evaluation are summarized in Table 4 (see later)

\subsection{Reduction of GHG emissions from 1990 levels}

The approach 'reduction of GHG emissions from 1990 levels' takes into account early mitigation action by countries. The EU aims for a $40 \%$ reduction relative to 1990 by 2030 . This is more ambitious than the NDC of the US, which consist of a $26-28 \%$ reduction target by 2025 relative to 2005 , which translates into around $27 \%$ below 1990 by 2030 (Figure 1). ${ }^{4}$

As mentioned in the previous section, this metric is not a good indicator for countries which differ in their stage of development, so we do not assess China by this criterion.

\subsection{Change in recent trends}

The rating for this criterion strongly depends on the reference point, and on the extent to which the effect of past action is included. We illustrate this using the NDCs of China, the EU, and the US.

For countries that have already implemented climate policies and have a downward trend in emissions, a further change in this trend may not be feasible. For those countries, the criterion does not take into account the efforts made earlier. The EU, for instance, has implemented a large number of climate policies in the past and is accelerating its downward trend of 1.0\% per year from 1990 to 2012 to $1.6 \%$ per year from 2012 until 2030 (based on own calculations, see Appendix for data sources (Supplementary Information). From this perspective, the 2020 pledge of a $20 \%$ reduction is quite weak, as it requires only a $0.1 \%$ annual decline from 2012 to 2020 . From that level to the new 2030 target of $40 \%$ would be a considerable step change requiring a $2.8 \%$ annual decline until 2030. But the EU is likely to reduce its emissions by more than $20 \%$ by 2020 (European Environmental Agency, 2014), with a projected annual reduction of 1.3\% from 2012 to 2020 . This implies that the annual reduction from 2020 to 2030 would need to be $1.9 \%$ to reach the 2030 target of $40 \%$. Therefore, in total, the new target constitutes a slight improvement in the trend.

The proposal of the US implies changing its current trend of $1.0 \%$ reduction per year from now until the 2020 target to $2.5 \%$ per year from 2020 until 2025 (in total also 1.6\% per year from 2012 to the NDC target). This implies a higher change in recent trends than the EU, although it is reducing at the same rate as the EU from 2012 to the target.

The comparison to a 'current policy scenario' (Figure 1) shows that the US targets constitute a significant deviation from the current policy scenarios. This could indicate a high ambition level for their NDC, but could also be an indication that policies lag behind the goals set in the NDC. The EU is close to achieving its NDC with already implemented policies. For a country with increasing emissions and/or limited climate policies, the emission trend can be significantly altered through the introduction of new policies. This applies to China in particular, where the proposal to peak emissions by 2030 is a significant deviation after 2030 from the usual reference assumption that emissions would continue to rise for decades after that ${ }^{5}$ (Tavoni et al., 2015). But as said before, this significantly depends on this reference assumption. For example, analysis suggests that the effect of all current policies is sufficient to meet the 20\% non-fossil target by 2030 (den Elzen et al., 2016; Grubb et al., 2015).

\subsection{Time and level of peaking of per capita emissions}

China's NDC includes the intention to peak in 2030 or earlier. We estimate that the peak in GHG emissions will be at around 9.0-9.6 $\mathrm{tCO}_{2}$ e per capita at a projected per capita GDP of $12,600 \mathrm{US}_{2005} .{ }^{6} \mathrm{GHG}$ emissions in the EU already peaked in 1979 at $13 \mathrm{tCO}_{2}$ e per capita (JRC/PBL, 2012) with a per capita GDP of 17,450 US\$2005, while emissions in the US peaked in 2007 at $24.5 \mathrm{tCO}_{2} \mathrm{e}$ per capita with a per capita GDP of 44,300 US\$2005. The GDP figures shown are based on GDP figures measured in market exchange rates (MER); if GDP measured in 


\section{China}

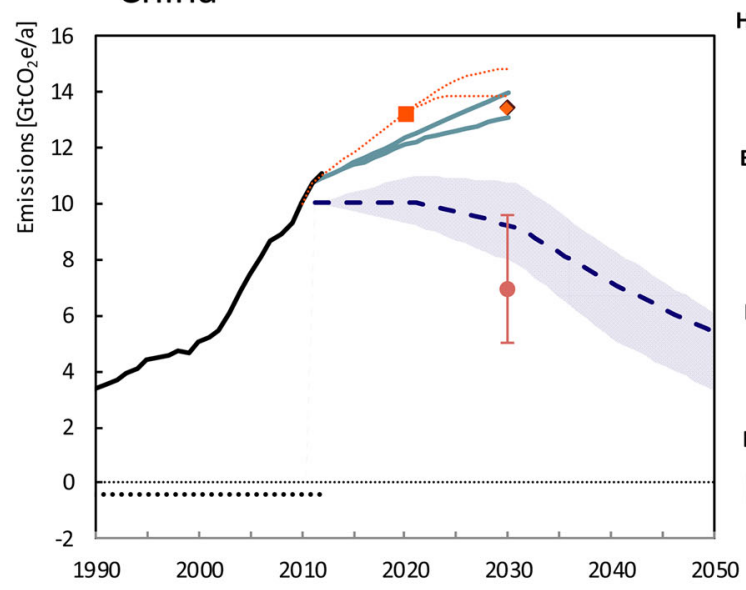

EU

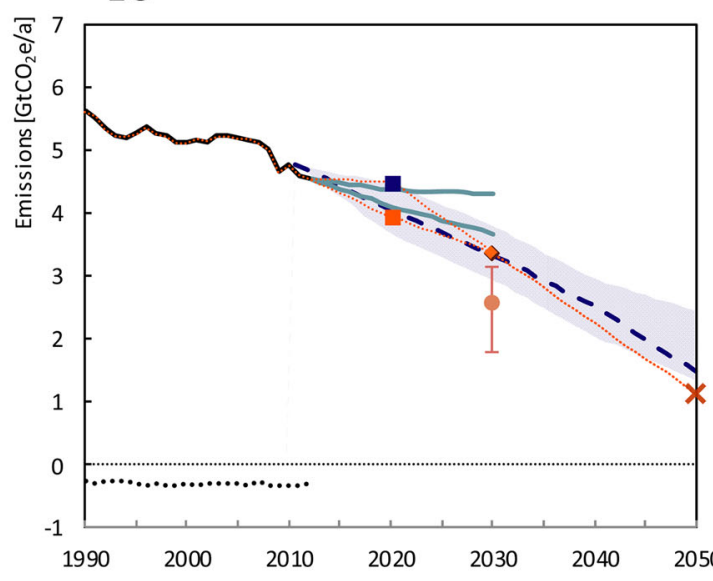

USA

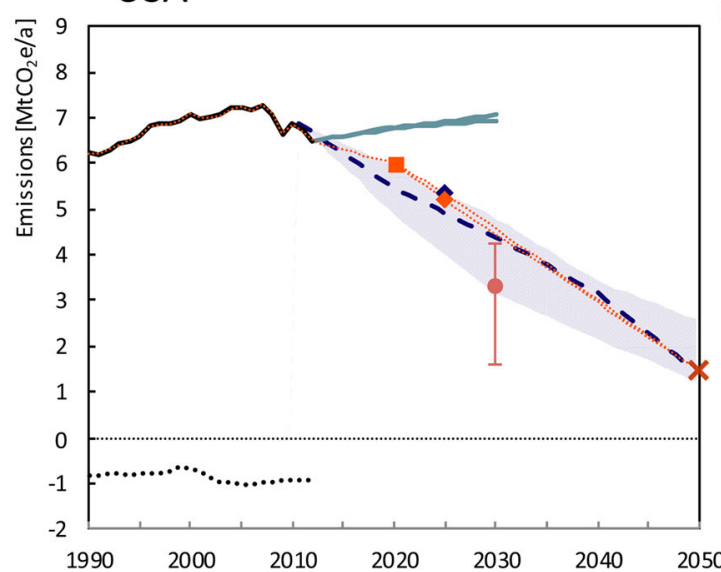

Historic and projected emissions

_ Historic emissions excl. LULUCF

...... Historic LULUCF emissions

Current policy projections

Emission reduction targets

- Copenhagen pledge

$\checkmark \quad$ NDC (non-fossilenergy target)

NDC (peaking and intensity targets)

Effort sharing

I Uncertainty (20th-80th percentile) range

Median

Least-cost scenarios

Uncertainty (10th-90th percentile) range

- Median

\section{Historic and projected emissions}

_ Historic emissions excl. LULUCF

...... Historic LULUCF emissions

Current policy projections

Emission reduction targets

- Copenhagen pledge

$\leftrightarrow \quad$ NDC

* Long-term commitment

Linear interpolation between targets

Effort sharing

I Uncertainty (20th-80th percentile) range Median

Least-cost scenarios

Uncertainty (10th-90th percentile) range

Median

Historic and projected emissions

Historicemissions excl. LULUCF

...... Historic LULUCF emissions

Current policy projections

Emission reduction targets

- Copenhagen pledge

- NDC

* Long-term commitment

.......... Linear interpolation between targets

Effort sharing

I Uncertainty (20th-80th percentile) range

- Median

Least-cost scenarios

Uncertainty (10th-80th percentile) range

Median

Figure 1. Emissions of China, the EU, and the US (see Appendix for sources and assumptions (Supplementary Information)). 
purchasing power parity were to be used, the per capita GDP for China would be a factor of more than three higher, and would therefore surpass the per capita GDP level of the EU at the peak year.

Comparing peaking levels at different points in time is not straightforward, because technological change allows countries to reach the same development level today with lower emissions than countries that developed earlier (den Elzen, Olivier, Höhne, \& Janssens-Maenhout, 2013). For example, the UK started its industrialization with inefficient steam engines, whereas developing countries that undergo a similar development today use best available current technology right away, which emits much less GHGs.

With this in mind, China is projected to peak its per capita emissions about 50 years after the EU, but at a level which is $27 \%$ lower (Green \& Stern, 2016). If technological progress implies that the emissions efficiency increases by $0.5 \%$ per year, it could be argued that countries that peak 50 years later in time, should peak at a level which is $22 \%$ lower, ${ }^{7}$ meaning that China will peak at a relatively lower level than the EU did. For an annual $1 \%$ increase in emissions efficiency, the peak should be $39 \%$ lower, meaning that the EU peaked at a relatively lower level. den Elzen et al. (2013) estimated an improvement rate of $1.3 \%$ per year during 1990 2005, owing to the combined effect of technological progress in energy efficiency and a transition to renewable energy sources, based on IEA statistics, ${ }^{8}$ which would mean that the EU peaked at a lower level than China is projected to do.

\subsection{Comparison to effort-sharing calculations}

In previous papers, the authors summarized effort-sharing calculations for the IPCC Fourth Assessment Report (Box 13.7 (Gupta et al., 2007) and its related papers (den Elzen \& Höhne, 2008)), as well as for the IPCC Fifth Assessment Report (Clarke et al., 2014; Höhne et al., 2014a) of the Intergovernmental Panel on Climate Change (IPCC) and provided country-level results for the Climate Action Tracker. ${ }^{9}$ Although most studies included in these assessment reports calculated country- or region-specific emissions allowance trajectories up to a certain future year (2030 or 2050), as reviewed in Höhne et al. (2014a), some studies also calculated remaining cumulative emissions allowances (de Vos, van Breevoort, Höhne, Winkel, \& Sachweh, 2014; Kuramochi et al., 2015).

Figure 1 provides ranges of GHG emission reduction targets for 2030 according to a wide variety of effortsharing approaches based on over 40 studies from various authors, some of which provide country-level data for the selected stabilization level $\left(450 \mathrm{ppm} \mathrm{CO}_{2} \mathrm{e}\right.$ ) (based on Figure 2 of Höhne et al. (2014a)). The results in Höhne et al. (2014a) are at the level of ten regions; for the US we have used the reduction percentages of the region North America (US, Canada), and for China, the region East Asia (incl. China, Korea, Mongolia). For the $\mathrm{EU}$, we applied a reduction percentage consisting of $70 \%$ of the results from the region Western Europe and of $30 \%$ from the region Economies in Transition, to take into account that the EU is part of both regions. As in Höhne et al. (2014a), the range is shown for all studies in all effort-sharing categories (except cost-effectiveness, as we consider this to be a separate approach, see Section 3.6) using the 20th to 80th percentile range.

Depending on the chosen effort-sharing approach, the reduction targets may differ significantly. Still, the full range of results can be used as an indication of the fairness of the countries' reduction proposals in relation to the $2^{\circ} \mathrm{C}$ goal.

Principles based on responsibility and capability considerations would usually result in higher reduction targets for developed countries owing to their higher economic capability and historical responsibility. At the extreme end, they would allocate zero or even negative emission allowances by 2030 to, for example, the US and the EU. Acknowledging that they cannot achieve these reduction targets domestically, these countries/ regions are expected to finance emission reductions in other countries. Developing countries' reduction targets are usually required to reduce later or less stringently.

Effort-sharing calculations provide a mixed picture across the three countries. The evaluation depends significantly on the choice of the effort-sharing approach or category and selection and weighting of the studies. Taking the effort-sharing data and methodology from the IPCC AR5 (Clarke et al., 2014; Höhne et al., 2014a), the reduction target calculated as the median over all studies for the US and China in 2030 is $51 \%$ (20th80th percentile range: 38-77\%) and 30\% (4-50\%) below their 2010 levels and for the EU 46\% (34-62\%) below its 1990 levels, which are all beyond their announced reduction targets, in particular for China. China ranks significantly better for approaches based on equal cumulative per capita emissions and those putting 


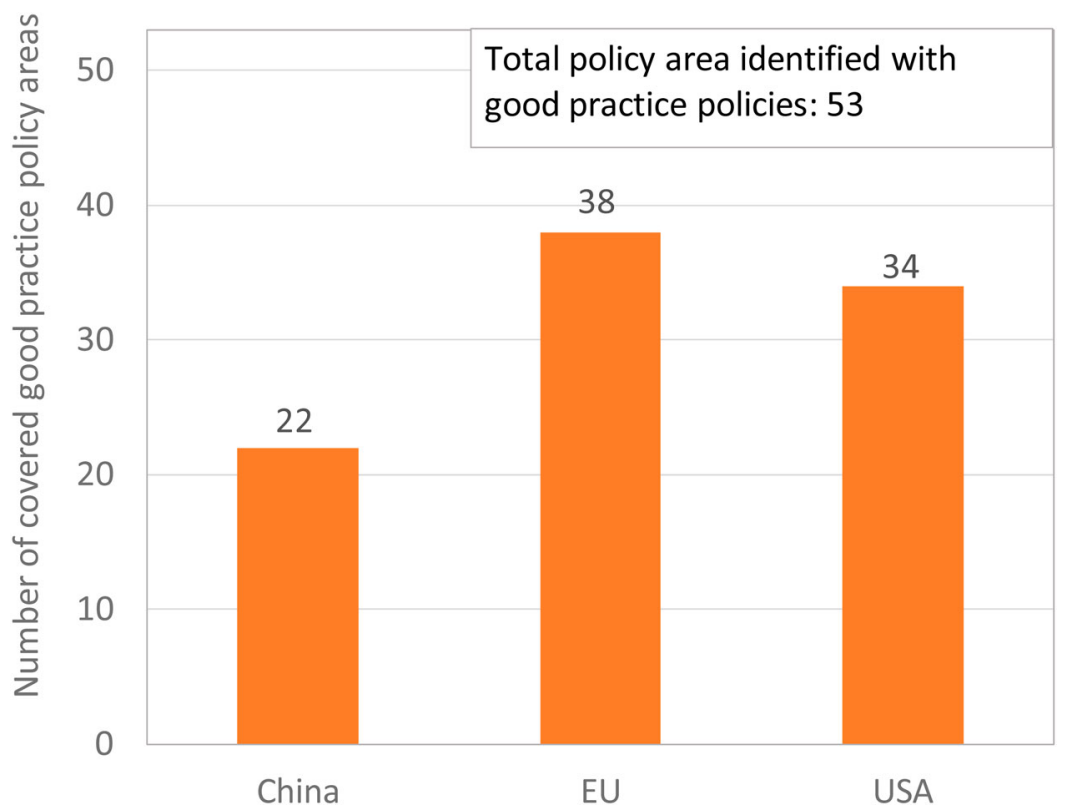

Figure 2. Number of good practice policy areas covered by currently implemented polices (based on Höhne et al., 2015).

high weights on responsibility and capability. The level of one study (from the 40 studies) is close to the Chinese proposal, but this study is in the 10th percentile, i.e. outside of the range shown here. The EU and US rate better for approaches that assume equal costs per GDP. The EU also rates better for the per capita emissions convergence approaches, given its lower per capita emissions by 2030 compared to the US and China.

\subsection{Comparison to benchmarks of sectoral decarbonization indicators}

China, the EU, and the US have proposed actions at the national level, not disaggregated to sectors (IEA, 2008; SDSN and IDDRI, 2014). To make an assessment of sectoral decarbonization indicators, a starting point could be model calculations that disaggregate national emissions to sectors, based on, for example, the planned national policies to achieve the overall targets. Such assessments show that the results of the comparison depends on the decarbonization indicator used (Climate Action Tracker, 2014; Cronin et al., 2015; IEA, 2012; UNFCCC, 2008).

By way of illustration, we provide a few decarbonization indicators implied by the NDCs in 2030 (Table 2). We derived these values from background material from the countries or from own calculations. We provide examples of 'activity rate' (e.g. how much floor space is used and how many kilometres are travelled) and a 'GHG emissions/energy intensity' (emissions per $\mathrm{m}^{2}$ floor area or per travelled kilometre). Both, together, determine the level of GHG emissions.

Table 2 shows that the EU has lower values than the US on per capita activity indicators (e.g. consumption levels such as electricity consumption and floor area) and on GHG emission intensities (e.g. $\mathrm{CO}_{2}$ emissions per kWh electricity generated or $\mathrm{CO}_{2}$ emissions per vehicle kilometre), both currently and in 2030. China's values on per capita activity levels are also lower than those of the US, but the picture is mixed for GHG/energy intensities. China's activity levels are lower than those of the EU, but some GHG/energy intensities are higher.

\subsection{Comparison to globally cost-effective $2^{\circ} \mathrm{C}$ scenarios}

Models have been used extensively, e.g. in the IPCC AR5 scenario database (Clarke et al., 2014), to come up with a range of global cost-effective scenarios, often also disaggregated to the country level, at least for the three considered here. A globally harmonized carbon price is applied in these models to equalize marginal abatement costs around the world. 
Table 2. Comparison of sector-level decarbonization indicators: current levels (for 2010-2014) and target levels as implied by the NDCs in 2030, where possible.

\begin{tabular}{|c|c|c|c|c|c|}
\hline \multirow{3}{*}{$\begin{array}{l}\text { Sector } \\
\text { Electricity generation (IEA, } \\
2015 \text { ) }\end{array}$} & \multicolumn{2}{|l|}{ Figures with recent developments } & \multirow{2}{*}{$\begin{array}{l}\text { China } \\
4000\end{array}$} & \multirow{2}{*}{$\frac{\mathrm{EU}}{6400}$} & \multirow{2}{*}{$\frac{\text { US }}{13,500}$} \\
\hline & Activity: electricity generation per capita $[\mathrm{kWh} / \mathrm{cap}]^{\mathrm{a}}$ & 2013 & & & \\
\hline & & $\begin{array}{l}2030 \text { (NDC } \\
\text { implementation case) }^{\mathrm{b}}\end{array}$ & 6500 & 6600 & 13,000 \\
\hline & Intensity: $\mathrm{CO}_{2}$ emission intensity $\left[\mathrm{gCO}_{2} / \mathrm{kWh}\right]$ & 2013 & 780 & 380 & 490 \\
\hline & & $\begin{array}{l}2030 \text { (NDC } \\
\text { implementation case) }\end{array}$ & 540 & 220 & 355 \\
\hline & Renewable energy share (incl. hydro) in total electricity & 2013 & $20 \%$ & $27 \%$ & $13 \%$ \\
\hline & & $\begin{array}{l}2030 \text { (NDC }^{\text {implementation case) }}{ }^{\text {b }}\end{array}$ & $30 \%$ & $44 \%$ & $24 \%$ \\
\hline \multirow[t]{4}{*}{ Industry } & \multirow{2}{*}{$\begin{array}{l}\text { Intensity: Energy saving potential for iron \& steel } \\
\text { production [GJ/t steel] }\end{array}$} & 2011 (IEA, 2014) & 6.7 & $1.6^{\mathrm{c}}$ & 2.1 \\
\hline & & 2030 & $\mathrm{~N} / \mathrm{A}$ & $\mathrm{N} / \mathrm{A}$ & $\mathrm{N} / \mathrm{A}$ \\
\hline & \multirow{2}{*}{$\begin{array}{l}\text { Intensity: Energy saving potential for cement production } \\
\text { [GJ/t cement] }\end{array}$} & 2010 (IEA, 2012) & 1.1 & 0.7 & 1.6 \\
\hline & & 2030 & $\mathrm{~N} / \mathrm{A}$ & N/A & $\mathrm{N} / \mathrm{A}$ \\
\hline \multirow{4}{*}{$\begin{array}{l}\text { Buildings (residential and } \\
\text { commercial) }\end{array}$} & \multirow[t]{2}{*}{ Activity: Building floor space per capita $\left(\mathrm{m}^{2} / \mathrm{cap}\right)^{\mathrm{d}}$} & 2013 & 40 & 57 & 100 \\
\hline & & 2030 (current trends) & 49 & 63 & 107 \\
\hline & \multirow[t]{2}{*}{ Intensity: final energy consumption per floor area $\left[\mathrm{MJ} / \mathrm{m}^{2}\right]^{\mathrm{e}}$} & 2013 & 390 & 660 & 640 \\
\hline & & $\begin{array}{l}2030 \text { (NDC } \\
\text { implementation case) }\end{array}$ & 350 & 590 & 550 \\
\hline \multirow[t]{4}{*}{ Transport } & \multirow{2}{*}{$\begin{array}{l}\text { Activity: Car ownership [passenger LDVs per } 1000 \text { persons) } \\
\text { (ICCT, 2012; World Bank data, 2015b) }\end{array}$} & 2010 & 44 & 480 & 740 \\
\hline & & 2030 (baseline case) & 210 & 610 & 820 \\
\hline & \multirow{2}{*}{$\begin{array}{l}\text { Intensity: Average } \mathrm{CO}_{2} \text { intensity of passenger LDVs }\left[\mathrm{gCO}_{2} /\right. \\
\mathrm{v}-\mathrm{km} \text { ] (Cronin et al., 2015) }\end{array}$} & 2014 & 210 & 155 & 215 \\
\hline & & 2030 (current trends) & 175 & 105 & 125 \\
\hline
\end{tabular}

Source: Various publications from the IEA (including data of the WEO2015 New policies Scenario IEA, 2015). For each indicator, the value leading to the lowest emissions is indicated in dark grey, the middle in grey and leading to the highest emissions in light grey.

${ }^{\mathrm{a}}$ Own calculation using the UN population projections (medium fertility variant) (United Nations, 2015).

${ }^{\text {b}}$ The WEO 2015 New Policies Scenario takes into account the energy-related components of the NDCs submitted as of 1 October 2015, but does not assume that all NDC targets are achieved.

${ }^{\mathrm{C}}$ For OECD Europe.

${ }^{d}$ Own calculations based on IEA (2014) and UN population projections (United Nations, 2015). Linear interpolation (for 2013) and extrapolation (for 2030) of the trends between 2011 and 2025 were performed.

'The 2013 and 2030 total floor area were estimated from the above-calculated per capita floor area and the population data from UN (United Nations, 2015). Final energy consumption data were taken from the IEA WEO 2015 New Policies Scenario (IEA, 2015).

For the global cost-effective emission pathways (also referred to as least-cost or cost-optimal pathways), we used the median estimate and the 10th-90th percentile range across the six modelled $2^{\circ} \mathrm{C}$ scenarios (Tavoni et al., 2015), scaled to the 2010 GHG emission estimate.

The models usually assume high mitigation potential and lower costs in developing countries, which is also visible for our three examples (Figure 1). The scenarios starting with immediate reductions prescribe faster reductions in China, e.g. peaking by 2020 or 2025 instead of 2030 as proposed by China. The EU and the US are broadly in the range of the cost-effective $2^{\circ} \mathrm{C}$ scenarios.

The assessment would be different if one would assume cost-optimal pathways from 2020 onwards (Tavoni et al., 2015); then also China would be in line with the cost-effective path.

\subsection{Comparison to a good practice policy package or a policy menu}

For a comparison of national climate policies, the critical element is the definition of the list of good practice policies that are used as benchmark. In this context, the UNFCCC secretariat has started to prepare policy menus (UNFCCC, 2014). The Climate Action Tracker team compared the policies of Australia and Mexico to a 
Table 3. Comparison of policy packages based on Fekete et al. (2015).

\begin{tabular}{|c|c|c|c|}
\hline & China & EU & US \\
\hline General & $\begin{array}{l}\text { - Nationally binding climate } \\
\text { targets with the 5-year plan }\end{array}$ & $\begin{array}{l}\text { - EU-wide binding climate law based on } \\
\text { several Directives }\end{array}$ & $\begin{array}{l}\text { - Government plan to use regulation, } \\
\text { but no nationally binding climate law }\end{array}$ \\
\hline $\begin{array}{l}\text { Energy } \\
\text { supply }\end{array}$ & $\begin{array}{l}\text { - Regional targets } \\
\text { - Mandatory closing of } \\
\text { inefficient power plants } \\
\text { - } \text { Renewable capacity targets } \\
\text { - Pilot emission trading systems } \\
\text { and national roll out }\end{array}$ & $\begin{array}{l}\text { - } \text { EU-wide emissions trading system } \\
\text { - } \text { Member state level binding renewable } \\
\text { targets } \\
\text { - Comprehensive support policies for } \\
\text { renewables }\end{array}$ & $\begin{array}{l}\text { - Clean power plan regulating } \\
\text { emissions per kWh } \\
\text { - State level renewable targets } \\
\text { - State level emission trading systems }\end{array}$ \\
\hline Industry & $\begin{array}{l}\text { - Targets for the top } 10,000 \\
\text { energy consuming companies } \\
\text { - Mandatory closing of } \\
\text { inefficient plants } \\
\text { - Pilot emissions trading } \\
\text { systems and national roll out }\end{array}$ & $\begin{array}{l}\text { - } \quad \text { EU-wide emissions trading system } \\
\text { - } \text { Member state level binding renewable } \\
\text { targets } \\
\text { - Comprehensive support policies for } \\
\text { renewables }\end{array}$ & $\begin{array}{l}\text { - Voluntary programmes } \\
\text { - Efficiency standards for industrial } \\
\text { motors } \\
\text { - State-level Emissions Trading Scheme }\end{array}$ \\
\hline Buildings & $\begin{array}{l}\text { - Building standards in } \\
\text { residential and commercial } \\
\text { sector } \\
\text { - Mandatory labelling }\end{array}$ & $\begin{array}{l}\text { - Building standards in residential and } \\
\text { commercial sector going to zero energy by } \\
2021 \\
\text { - Efficiency standards for broad range of } \\
\text { appliances }\end{array}$ & $\begin{array}{l}\text { - Building standards in residential and } \\
\text { commercial sector } \\
\text { - Mandatory labelling for a broad range } \\
\text { of appliances }\end{array}$ \\
\hline Transport & $\begin{array}{l}\text { - } \text { Car standard } \\
\text { - Truck standard } \\
\text { - Biofuel support } \\
\text { - Tax incentives for energy } \\
\text { efficient cars }\end{array}$ & $\begin{array}{l}\text { - Car standard (most ambitious level of the } \\
\text { three countries) } \\
\text { - Truck standard } \\
\text { - Tax incentives and quota for biofuels }\end{array}$ & $\begin{array}{l}\text { - Light duty vehicle standard } \\
\text { - Truck standard } \\
\text { - Tax incentives and quota for biofuels }\end{array}$ \\
\hline
\end{tabular}

good practice policy package (Ecofys \& Climate Analytics, 2011, 2012). An initial comprehensive collection of a good practice policy package and an assessment of whether countries have implemented a list of good practice policies has been performed by Fekete et al. (2015) and Höhne, Fekete, Kuramochi, lacobuta, and Prinz (2015). Based on this previous work we provide a short overview of policies (Table 3).

Given that some countries are clearly more ambitious than others in some areas, an unambiguous overall ranking is not possible. The EU is clearly more ambitious with its nationally binding climate law and more than 10 Directives, as the US does not have a nationally binding climate law. However, determining whether the approach to efficiency in industry is more ambitious in China, the EU or the US cannot unambiguously be done.

Another approach is to look at how many policy areas are covered that could be considered good practice policies. Höhne et al. (2015) developed a matrix of policies by sector and thematic area (e.g. energy efficiency, renewable energy, shift in lifestyle or economic activity, etc.), identified policy measures that are considered as 'good practice' for each policy area (e.g. fuel economy standards in the transport sector) based on a literature review, and assessed to what extent the major countries cover the good practice policy matrix.

Preliminary results of Höhne et al. (2015) for China, the EU, and the US before COP21 are presented in Figure 2. Based on the policy data gathered from various sources, the EU was leading over the US and China in terms of the coverage of policy areas with good practice policies. Nevertheless, even for the EU, about $30 \%$ of the policy areas are not yet covered with good practice policies, indicating the need for further efforts.

The results likely depend on the definition of the areas of good practice as well as the availability of up-todate policy information. Moreover, only looking at whether good practice policies exist disregards the effectiveness of the implemented policies.

The three countries/regions have not explained in detail which policies they are going to use to implement their NDC. It is crucial to investigate what kind of policy measures are envisioned in each country/region to achieve the 
Table 4. Assessment of the ambition of the NDCs of China, the EU, and the US using various evaluation approaches.

China (Peaking $\mathrm{CO}_{2}$ around $2030 ; 60-65 \% \mathrm{CO}_{2}$

emission intensity reduction; $20 \%$ non-fossil

fuels in primary energy consumption)

EU (at least $40 \%$ below 1990 by 2030)

US ( $-26 \%$ to $28 \%$ below 2005 by 2025$)$

NDC description

Method

Rank

Approaches related mainly to moral obligation

Reduction from 1990 levels

Change in recent trend

Change compared to 'current policy scenario'

Time and level of peaking of per capita emissions

\section{Comparison to equity-based effort-sharing}

\section{calculations}

Median estimate of GHG emission allowances based on

effort-sharing data from the IPCC AR5 (20th-80th

percentile range).

\section{Approaches related mainly to technical necessity}

Comparison to benchmarks of decarbonization

\section{indicators}

Number of indicators in the lead (see Table 2)

Number of indicators second

In line with globally cost-effective model pathways

Starting in 2010

(10th-90th percentile range of emissions)

Starting in 2020

(10th-90th percentile range of emissions)

Comparison to best practice policy package or policy

menu

Number of good practice policy areas covered by

currently implemented polices

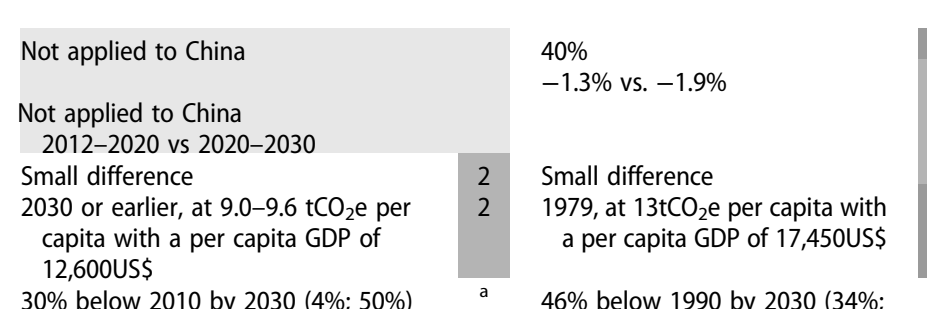

30\% below 2010 by 2030 (4\%; 50\%)

(compared to $48 \%$ above 2010

levels with NDC)

46\% below 1990 by 2030 (34\%;

$62 \%)$

(compared to $40 \%$ below 1990 with NDC

Rank

$27 \%$

$-1.0 \%$ vs. $-2.5 \%$

2 Significant difference

2007 , at $24.5 \mathrm{tCO}_{2}$ e per capita with a

per capita GDP of 44,300 US\$

$51 \%$ below 2010 by 2030 (38\%; 77\%) (compared to $34 \%$ below 2010 by 2030 under the extrapolated $\mathrm{NDC}^{\mathrm{b}}$ )

8

Not in line (5\% above 2010 to $20 \%$ below 2010 levels)

In line $(20 \%$ to $55 \%$ above 2010 levels) levels)

In line (20 to 30\% below 2010 levels)

\section{8}

1

0

In line (30 to 55\% below 2010 levels)

In line (30 to $40 \%$ below 2010 levels)

34

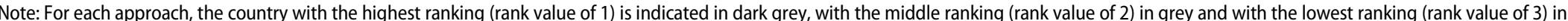
light grey.

${ }^{a}$ No rank provided.

${ }^{\mathrm{b}}$ Extrapolated to 2030 based on a linear path towards the 2050 target of 83\% below 2005 levels and took the average over the high and low 2025 target. 
mitigation targets under the NDCs. It may be that one country with a low coverage of policies needs to increase its coverage significantly to meet its NDC, whereas another country would need to add only a little.

\subsection{Summary evaluation}

In a final step, we summarize the results for the three countries/regions (Table 4). The table includes the evaluation results as well as a relative ranking among the three. If a ranking could not be determined unambiguously, we have applied the same rank.

As expected, examples score very differently between the approaches. However, the overview of the ensemble of the results shows certain tendencies. For example, the EU scores first among the three on many approaches (in many cases together with China and or the US). Only on changes in recent trends is the US clearly ahead of the EU. This coincides with the countries' own explanations of the level of ambition of their approaches: The NDC of the US states that 'Achieving the 2025 target will require a further emission reduction of $9-11 \%$ beyond our 2020 target compared to the 2005 baseline and a substantial acceleration of the 20052020 annual pace of reduction, to 2.3-2.8 percent per year, or an approximate doubling.'

The comparison of China and the US is, in essence, determined by how far the different development levels should be taken into account: China is consistently ahead of the US in decarbonization indicators and in level and timing of peaking emissions. Owing to a lower development level, its emission intensity and activity levels are lower than in the US. The US, on the other hand, has a more comprehensive policy package and proposes more change from the current policy scenarios.

As the NDCs in aggregate are insufficient to meet the long-term goals of the Paris Agreement (Rogelj et al., 2016), the total ambition level has to be increased. The overview evaluation directly shows the shortcomings of the NDCs and therefore provides hints to where improvements could take place. Although the EU scores well on many aspects, our framework shows that the current NDC constitutes only limited progression from current trends. Even with a step change in policy, our comparison of approaches shows that activity and energy intensity levels in the US are still much higher than in other countries. Regarding China, although its activity and energy intensity indicators are still low and it is undertaking significant policy efforts in some areas, the analysis reveals that many policy areas remain unaddressed.

How robust is this evaluation? The overview of the results may depend on the selection of the evaluation approaches. To minimize this point, we have deliberately selected many approaches and have not aggregated the results into one rating. This would have put even more emphasis on the selection and weighting of the approaches.

Future analyses of this kind could split the effort-sharing evaluation into more categories, which would give these points more implicit weight. Future research could also include more studies, and therefore be more precise on the percentiles where countries' NDCs lie.

An important caveat with the analysis is that some of the indicators require a reference scenario, which is hard to define. This is especially the case for the approaches 'Change in trend' and 'In line with globally costeffective $2^{\circ} \mathrm{C}$ scenarios'. These approaches are only constructive for climate negotiations if countries can agree on the reference scenario or at least its definition. Another caveat is that, although our method works well for comparing the proposals of a few countries, a comparison with many countries may prove difficult owing to the extent of data and analysis effort needed.

While providing a range of approaches for comparing ambition, we still do not take into account general social, political and institutional factors, which may influence a consideration of ambition levels.

The major advantages of our method are its transparency and the fact that many viewpoints with regard to fairness are taken into consideration. It automatically reveals the strengths and weaknesses of the emission reduction proposals. Furthermore, it can reveal quite clearly whether a proposal really scores well or not on many perspectives or only from a limited set of viewpoints.

\section{Conclusions}

One of the key elements of the Paris Agreement are the post-2020 contributions that most countries have submitted before the Paris climate summit. For the functioning of the Paris Agreement with constantly new and 
strengthened national contributions it is of crucial importance that countries can judge how the proposals of other countries compare to their own proposal.

In this article, we identified eight approaches from the review of a large variety of approaches to assess the ambition of the post 2020 climate proposals (NDCs) by countries. We applied seven evaluation approaches (where sufficient data were available) illustratively to the NDCs of China, the EU, and the US.

We draw the following conclusions:

First, a comprehensive assessment of ambition of climate proposals can only be undertaken using a large variety of evaluation approaches. Each single approach has its pros and cons, starts from a very particular perspective, and no single approach is truly comprehensive. The different nature of the evaluation approaches leads to different outcomes; only if all of them are applied, does it become evident if a country is broadly ambitious, or only under very selective perspectives. Such a comprehensive approach could therefore be usefully applied as preparation for the facilitative dialogue in 2018 , and the global stocktake that is to take place every five years starting from 2023.

Second, we put forward just such a comprehensive framework of evaluation approaches that covers, to our knowledge, the broadest possible range of approaches. The framework would evaluate countries using all eight approaches shown here, rank countries relative to each other where possible, and present the results alongside each other (without aggregating into one overall rating). The illustrative cases of China, the EU, and the US show that such a comparison is very insightful, and can result in concrete suggestions for improving the NDCs.

Finally, we find that the ambition level of China, the EU, and the US varies, depending on the perspective. The EU ranks consistently first or second across many of the approaches. Only on changes in recent trends is the US clearly ahead of the EU. The comparison of China and the US is, in essence, determined by how far the different development levels should be taken into account.

Several research questions are still open: complete sets of decarbonization indicators, also covering future developments under the NDCs, are still lacking. Furthermore, comprehensive comparisons of policies implemented by countries have to be undertaken. Globally cost-effective pathways would best be disaggregated by as many countries as possible (currently, most studies distinguish only up to around 25 regions). Finally, new calculations would need to be undertaken that are compatible with $1.5^{\circ} \mathrm{C}$, as such scenarios are currently covered only to a limited extent.

This future research should be undertaken urgently, so that a comprehensive framework as proposed here can be applied at the 2018 facilitative dialogue in 2018 and the 2023 global stocktake.

\section{Notes}

1. UNFCCC decision 1/CP.19, http://unfccc.int/resource/docs/2013/cop19/eng/10a01.pdf\#page=3.

2. We have not included the criterion 'universal applicability' of Aldy et al. (2016), because all approaches included in our assessment are universally applicable.

3. The criterion excluded from the analysis are energy price indicators including carbon prices as there are few data available on future energy and carbon prices under NDCs in respective countries.

4. The target translates to $14-16 \%$ below 1990 in 2025 . We extrapolated to 2030 based on a linear path towards the 2050 target of $83 \%$ below 2005 levels and took the average over the high and low 2025 target.

5. For example, the emission level in 2030 is $8-15 \%$ below the Chinese business-as-usual emission projections (no policy scenarios) of the modelling comparison study (Tavoni et al., 2015), whereas the median of the Chinese business-as-usual projections peaks at 2080 .

6. The GDP figures are measured in market exchange rates (MER) and the historical estimates are based on World Bank data (2015a). The GDP projections are based on the GDP growth estimates of the World Energy Outlook 2014 for the 2030 projection of China

7. $(100 \%-0.5 \%)^{\wedge} 50-100 \%=-22 \%$.

8. More specifically, this is based on the combined effect of innovation on emissions efficiency improvement of about $0.8 \%$ per year for 1990-2005, and the autonomous emissions improvement over total primary energy supply owing to transition to renewable energy sources of $0.5 \%$ (IEA, 2008).

9. www.climateactiontracker.org.

10. www.climateactiontracker.org. 


\section{Acknowledgements}

The authors thank the colleagues from the Climate Action Tracker ${ }^{10}$ team for the fruitful and inspiring discussions. We also thank the anonymous reviewers for their thoughtful comments which significantly improved this article.

\section{Disclosure statement}

No potential conflict of interest was reported by the author(s).

\section{ORCID}

Niklas Höhne (D) http://orcid.org/0000-0001-9246-8759

Michel G.J. den Elzen (iD http://orcid.org/0000-0002-5128-8150

Andries F. Hof (iD http://orcid.org/0000-0002-7568-5038

Takeshi Kuramochi (D) http://orcid.org/0000-0002-3976-0133

\section{References}

Aldy, J. E., Pizer, W. A., \& Akimoto, K. (2016). Comparing emissions mitigation efforts across countries. Climate Policy, 1-15. doi:10.1080/ 14693062.14692015 .11119098

Clarke, L., Jiang, K., Akimoto, K., Babiker, M. H., Blanford, G., Fisher-Vanden, K., ... van Vuuren, D. P. (2014). Assessing transformation pathways. In O. Edenhofer, R. Pichs-Madruga, Y. Sokona, E. Farahani, S. Kadner, K. Seyboth, ... J. C. Minx (Eds.), Climate change 2014: Mitigation of climate change. Contribution of working group III to the fifth assessment report of the intergovernmental panel on climate change (pp. 418-491). Cambridge: Cambridge University Press.

Climate Action Tracker. (2014). China, US and EU post - 2020 plans reduce projected warming. Climate Action Tracker Policy Brief. Retrieved from http://climateactiontracker.org/assets/publications/briefing_papers/CAT_Briefing_10122014.pdf

Cronin, C., Menon, S., Monteith, S., Plechaty, D. M. H, Höhne, N., Sterl, S., ... Sferra, F. (2015, December). Faster and Cleaner: Decarbonization in the power and transport sectors is surpassing predictions and offering hope for limiting warming to $2^{\circ} \mathrm{C}$. ClimateWorks, NewClimate Institute, Ecofys, and Climate Analytics.

Ecofys \& Climate Analytics. (2011). Assessment of Australia's policies impacting its greenhouse gas emissions profile. Climate Analytics, Ecofys and the Potsdam Institute for Climate Impact Research (PIK). Retrieved from www.climateanalytics.org/

Ecofys \& Climate Analytics. (2012). Assessment of Mexico's policies impacting its greenhouse gas emissions profile. Climate Analytics, Ecofys and the Potsdam Institute for Climate Impact Research (PIK), www.climateanalytics.org/

den Elzen, M. G. J., Fekete, H., Höhne, N., Admiraal, A., Forsell, N., Hof, A. F., ... van Soest, H. (2016). Greenhouse gas emissions from current and enhanced policies of China until 2030: Can emissions peak before 2030? Energy Policy, 89, 224-236.

den Elzen, M. G. J., \& Höhne, N. (2008). Reductions of greenhouse gas emissions in annex I and non-annex I countries for meeting concentration stabilisation targets. Climatic Change, 91, 249-274.

den Elzen, M. G. J., Höhne, N., \& van Vliet, J. (2009). Analysing comparable greenhouse gas mitigation efforts for annex I countries. Energy Policy, 37, 4114-4131.

den Elzen, M. G. J., Olivier, J. G. J., Höhne, N., \& Janssens-Maenhout, G. (2013). Countries' contributions to climate change: Effect of accounting for all greenhouse gases, recent trends, basic needs and technological progress. Climatic Change, 121(2), 397-412.

European Council. (2014). European Council (23 and 24 October 2014) Conclusions on 2030 Climate and Energy Policy Framework, Brussels. Retrieved from http://www.consilium.europa.eu/uedocs/cms_data/docs/pressdata/en/ec/145356.pdf

European Environmental Agency. (2014). Trends and projections in Europe 2014. Tracking progress towards Europe's climate and energy targets for 2020.

Fekete, H., Roelfsema, M., Höhne, N., den Elzen, M. G. J., Forsell, N., \& Becerra, S. (2015). The impact of good practice policies on regional and global greenhouse gas emissions. NewClimate Institute, PBL Netherlands Environmental Assessment Agency and the International Institute for Applied Systems Analysis, Cologne, Germany, Retrieved from http://newclimate.org/2015/07/29/theimpact-of-good-practice-policies-on-regional-and-global-greenhouse-gas-emissions/

Green, F., \& Stern, N. (2016). China's changing economy: Implications for its carbon dioxide emissions. Climate Policy. doi:10.1080/ 14693062.2016.1156515

Grubb, M., Sha, F., Spencer, T., Hughes, N., Zhang, Z., \& Agnolucci, P. (2015). A review of Chinese $\mathrm{CO}_{2}$ emission projections to 2030 : The role of economic structure and policy. Climate Policy, 15, S7-S39.

Gupta, S., Tirpak, D. A., Burger, N., Gupta, J., Höhne, N., Boncheva, A. I., ... Sari, A. (2007). Policies, instruments and Co-operative arrangements. In B. Metz, O. R. Davidson, P. R. Bosch, R. Dave, \& L. A. Meyer (Eds.), Climate change 2007: Mitigation. Contribution of working group III to the fourth assessment report of the intergovernmental panel on climate change (pp. 745-807). Cambridge: Cambridge University Press.

Hof, A. F., den Elzen, M. G. J., \& Mendoza Beltran, A. (2016). The EU 40\% greenhouse gas emission reduction target by 2030 in perspective. International Environmental Agreements: Politics, Law and Economics, 16(3), 375-392. 
Höhne, N., Blok, K., Hagemann, M., Moltmann, S., Fekete, H., Hänsel, G., ... Schaeffer, M. (2011). Climate action tracker - Country assessment methodology. Ecofys, Climate Analytics. Retrieved from http://climateactiontracker.org/assets/publications/publications/ WP1_MethodologyCountryAssessment_website_2011.pdf

Höhne, N., den Elzen, M. G. J., \& Escalante, D. (2014a). Regional greenhouse gas mitigation targets based on equity principles: A comparison of studies. Climate Policy, 14, 122-147.

Höhne, N., Ellerman, C., \& Fekete, H. (2014b). Knowledge product. Process guidance for Intended Nationally Determined Contributions (INDCS). International Partnership on Mitigation and MRV

Höhne, N., Fekete, H., Kuramochi, T., lacobuta, G., \& Prinz, L. (2015). Progress towards good practice policies for reducing greenhouse gas emissions. Initial results from an analysis of the status of climate related policies in 30 countries. NewClimate Institute, Cologne, Germany, Cologne, Germany, Retrieved from https://newclimate.org/2015/12/01/good-practice-policies/

Höhne, N., Kuramochi, T., Warnecke, C., Röser, F., Fekete, H., Hagemann, M., ... Gonzales, S. (2016). The Paris agreement: Resolving the inconsistency between global goals and national contributions. Climate Policy, 17(1), 16-32.

ICCT. (2012). Global transportation roadmap: Model Documentatio and user guide. ICCT Roadmap Model Version 1-0, The International Council on Clean Transpo. Retrieved from www.theicct.org/transportation-roadmap

International Energy Agency. (2008). Worldwide trends in energy use and efficiency. Paris: Author.

International Energy Agency. (2012). Energy technology perspectives 2012: Pathways to a clean energy system. Paris: Author.

International Energy Agency. (2014). Energy technology perspectives 2014: Harnessing electricity's potential. Paris: Author.

International Energy Agency. (2015). World energy outlook 2015. Paris: OECD/IEA.

JRC/PBL. (2012). EDGAR version 4.2 FT2010. Joint Research Centre of the European Commission/PBL Netherlands Environmental Assessment Agency. Retrieved from http://edgar.jrc.ec.europa.eu/index.php

Kuramochi, T. (2015). How do we evaluate the ambition level of INDCs ex-ante? An initial assessment on Japan. In K. Tamura, S. Kojima, T. Kuramochi, M. Suzuki, Y. Madoka, Y. Yu, ... M. Nakata (Eds.), The Paris climate agreement and beyond: Linking short-term climate actions to long-term goals (pp. 69-88). Hayama: Institute For Global Environmental Strategies.

Kuramochi, T., Asuka, J., Fekete, H., Tamura, K., \& Höhne, N. (2015). Comparative assessment of Japan's long-term carbon budget under different effort-sharing principles. Climate Policy, 16(8), 1029-1047.

Linthorst, G., de Beer, J., Blok, K., \& Meindertsma, W. (2014). Science based targets - Driving ambitious corporate climate action. CDP, World Resources Institute (WRI), WWF, Ecofys

Meinshausen, M., Jeffery, L., Guetschow, J., Robiou Du Pont, Y., Rogelj, J., Schaeffer, M., ... Meinshausen, N. (2015). National post-2020 greenhouse gas targets and diversity-aware leadership. Nature Climate Change, 5, 1098-1106.

NIES. (2015). Climate change mitigation Policy Progression Indicator (CPPI). National Institute for Environmental Studies, Japan: Tsukuba, Japan, Retrieved from https://www.nies.go.jp/media_kit/2015/7.3.pdf

Rogelj, J., Den Elzen, M., Höhne, N., Fransen, T., Fekete, H., Winkler, H., .. Meinshausen, M. (2016). Paris Agreement climate proposals need a boost to keep warming well below $2^{\circ} \mathrm{C}$. Nature, 534, 631-639.

SDSN, IDDRI. (2014). Pathways to deep decarbonization. 2014 Report. Sustainable Development Solutions Network \& Institute for Sustainable Development and International Relations. Retrieved from http://unsdsn.org/wp-content/uploads/2014/09/DDPP Digit.pdf

Stavins, R., Zou, J., Brewer, T., Conte Grand, M., den Elzen, M., Finus, M., ... Winkler, H. (2014). International cooperation: Agreements and instruments. In O. Edenhofer, R. Pichs-Madruga, Y. Sokona, E. Farahani, S. Kadner, K. Seyboth, ... J. Minx (Eds.), Climate change 2014: Mitigation of climate change. Contribution of working group III to the fifth assessment report of the intergovernmental panel on climate change (pp. 1001-1081). Cambridge: Cambridge University Press.

Tavoni, M., Kriegler, E., Riahi, K., van Vuuren, D. P., Aboumahboub, T., Bowen, A., ... van der Zwaan, B. (2015). Post-2020 climate agreements in the major economies assessed in the light of global models. Nature Climate Change, 5, 119-126.

UNFCCC. (2008). Synthesis of information relevant to the determination of the mitigation potential and to the identification of possible ranges of emission reduction objectives of Annex I Parties: an update. UNFCCC document FCCC/TP/2008/10. Retrieved from http:// unfccc.int/resource/docs/2008/tp/10.pdf

UNFCCC. (2010a). Decision 1/CP.16. The Cancun Agreements. UNFCCC document FCCC/CP/2010/7/Add.1. Retrieved from http://unfccc. int/resource/docs/2010/cop16/eng/07a01.pdf\#page $=2$

UNFCCC. (2010b). Report of the Conference of the Parties on its fifteenth session, held in Copenhagen from 7 to 19 December 2009 , document FCCC/CP/2009/11/Add.1. Retrieved from http://unfccc.int/resource/docs/2009/cop15/eng/11a01.pdf

UNFCCC. (2014). Updated compilation of information on mitigation benefits of actions, initiatives and options to enhance mitigation ambition. Technical paper, FCCC/TP/2014/3. Retrieved from www.unfccc.int

UNFCCC. (2015a). Adoption of the Paris Agreement. Proposal by the President. Draft decision -/CP.21. Conference of the Parties. Twentyfirst session, Paris, 30 November to 11 December 2015. FCCC/CP/2015/L.9/Rev.1, United Nations Framework Convention on Climate Change.

UNFCCC. (2015b). Intended Nationally Determined Contributions (INDCs). Retrieved from http://www4.unfccc.int/submissions/indc/ Submission\%20Pages/submissions.aspx

United Nations. (2015). World population prospects: The 2015 revision. DVD Edition. United Nations, Department of Economic and Social Affairs, Population Division.

de Vos, R., van Breevoort, P., Höhne, N., Winkel, T., \& Sachweh, C. (2014). Assessing the EU 2030 Climate and Energy targets. A briefing paper. Ecofys, Utrecht, the Netherlands, Retrieved from http://www.ecofys.com/files/files/ecofys-2014-assessing-the-eu-2030targets.pdf 
White House. (2014). U.S.-China Joint Announcement on Climate Change, Beijing, China. Retrieved from http://www.whitehouse.gov/ the-press-office/2014/11/11/us-china-joint-announcement-climate-change

Winkler, H., \& Rajamani, L. (2014). CBDR\&RC in a regime applicable to all. Climate Policy, 14, 102-121.

World Bank data. (2015a). Retrieved from http://data.worldbank.org/datacatalog/world-development-indicators

World Bank data. (2015b). Retrieved from http://data.worldbank.org/indicator/IS.VEH.PCAR.P3 